aboriginal technology and they intermarried. Traders did not change the fundamental society.

In later chapters McCormack uses an analytical approach popularized in the 1990s by historians such as Jean and John Comaroff who concluded that colonialism transforms the consciousness of its subjects in ways they may not be fully aware of. Influences such as education, religion, and the imposition of law may not directly aim at conquest, but help to accomplish it. Although sympathetic to this argument as it applies to aboriginal people in Canada and conscious of the expectation of Canadian bureaucracy that aboriginal people would be assimilated, McCormack also identifies instances of resistance, if not at Fort Chipewyan, then in neighbouring Treaty 8 regions.

When faced with the decision of accepting Treaty 8 or "Metis" scrip in 1899, aboriginal people in Fort Chipewyan were at a relative disadvantage, but they were not naive. They knew the history of Treaty 6 and had spoken to Metis from the South. They did not want to be restricted to living on reserves. They negotiated future hunting, fishing, and trapping rights and in the case of Alexandre Laviolette, access to Roman Catholic Schools. He also wanted a railroad, a convenience not promised and yet to be realized. The problem was not negotiating, but having the negotiated rights honoured.

In her epilogue McCormack argued that Fort Chipewayn people have always successfully adjusted to economic and cultural change. For the most part, Fort Chipewyan people have assimilated outsiders rather than assimilating to outside society. She concludes the community had more difficulty adjusting in post-treaty Canada with the imposition of Euro-Canadian managers. Yet, she states they never lost sight of their wish to be free, and with the help of court rulings since the 1970s they are acquiring the tools that they need to do so.

Daniel Johns

Alberta Ombudsman

\title{
Terry Sullivan, The Cburch of the Empire Versus the Christian Cburch of North Africa: 312-430 AD (Denver: Radical Christian Press, 2012).
}

During a recent presentation at U.C. Berkeley, Princeton professor of African American Studies Cornell West commented, "Most of Christianity is Constantinian Christianity." What did he mean? In his new book, The Church of the Empire, the church historian and former New York Catholic Worker associate, Terry Sullivan, endeavors to give us an answer to this in his account of the 
fourth century transmutation of the primitive Christian Church into the comfortable Catholic Church we encounter during and after the reign of the Emperor Constantine (272-337 AD).

But Sullivan's book is more than a history report. He states where he is coming from in the very first sentence, "The secular Christianity which was established by the worldly church of the Roman Empire is the enemy of Christian society which must be built upon the true Christian morality that was preserved, revived, and renewed in the underground church." Church of the Empire's history takes on those who apologize for Constantine, such as art historian Kevin Johnson, who writes:

Two candidates for emperor, Constantine and Maxentius, were about to meet in a decisive battle at the Milvan Bridge in 312. The night before the battle, Constantine saw a bright vision in the sky: a great cross with the legend "in this sign you shall conquer." Grateful for the divine aid, he took an interest in Christianity, supporting it with gifts of land and treasure, building immense churches and presiding at synods of bishops in his palace.

In refuting the imperial version of history, Sullivan uses the letters of Augustine of Hippo (354-430 AD) and other early sources, as he guides us through a realistic picture of the political marriage (or affair) between the Christian church and Constantine's ambitions. The canvas for this portrait is North Africa and its primitive bishops; the most notable of them being the establishment antagonist Donatus (d. 355). Both sides in this conflict (as well as Sullivan) use the word "satanic" to describe their opponents and their ends. On one side we see the new establishment Christians refer to the followers of Donatus as "sons of hell." On the other side is the condemnation by Tyconius (370-390 AD) of the establishment Catholics as:

Evil priests working with the kings of this world. Relying on royal favor they have renounced Christ. . They confess and speak through their works that, "We have no other king but Caesar." (85).

Where previous generations of African Christians had seen the Emperor and his officials as personifications of the devil, Augustine told the Donatists "There is no braver soldier of Christ than the Emperor." The Cross became a military standard and "the Prince of Peace was turned into the war god of an evil empire," as Sullivan summarizes in quoting John Henry Newman:

For the first time, the meek and peaceful Jesus became a god of battle, and the Cross the holy sign of Christian Redemption, a banner of bloody strife. This was the first advance to the military Christianity of the middle ages, a 
modification of the pure religion of the Gospel, if directly opposed to its genuine principles. (29-30).

Make no mistake, the Church of the Empire is trying to get us to look behind the curtain of Augustine's theological speculations and see, as the book puts it, that, "The Emperor's adoption of Bishop Caecilian of Carthage [311 $\mathrm{AD}$ ] was the beginning of a long battle between the Christians of North Africa and the Imperial Forces behind the new state church. The battle wasn't between the 'Donatist' Church and the 'Catholic' Church; the battle was between the Christian Church and the Roman Empire. (16).

We are invited to look not only at the great civil war that ended with the Battle of the Milvan Bridge but at the many rebellions that went on in North Africa before the war. Later on in the midst of the great theological councils, Constantine is seen as continuing the war by laying out a system where bishops are deposed, bought, or made Roman officials such as judges. In this system, corruption and absenteeism ran rampant; the charge of theological error became a good way for Augustine to push enemies aside, or get rid of them altogether. In this imperial church, three thousand bags of gold could buy a lot.

For those who yelled, "Don't Take the Money!" like Donatus, the remedy of the imperial church became the charge of heresy. This was made a crime punishable by torture or death. It was at this time that the disconcerting birth of "police Christianity" reared its holy head with armed Roman enforcers and the picture of the Virgin Mary, "Mother of Battles" leading the way. This militant Mary regularly appeared thereafter as historian Kevin Johnson shows in his discussion of Mary at the Battle of Lepanto. At Lepanto Christian Europe and the Muslim Ottoman Empire met in 1571. The rosary was invoked to gain the help of "Our Lady of Victory."

Sullivan argues that in its early years and later, "A primary mark of the true church was that it was persecuted for its adherence to the Christian faith." (4). In this regard he quotes both Bishop Donatus, "What has the Emperor to do with the Church?” and also his successor, Bishop Parmenian (385 AD), "What have Christians to do with Kings, or Bishops with the Palace?" (22, 85). Sullivan contrasts this with the religious persecution of Caligula, which was imitated by Constantine. This persecution, says Sullivan, became a mark of the false church.

This book would serve well as a textbook in church history, peace studies, or liberation theology, and it will reward the general reader with its many insights into a rich part of the Christian tradition.

Will Roach

Loyola Institute for Ministry 